\title{
Mitos Gaya Hidup Metroseksualitas dalam Iklan Produk Kosmetik Vaseline Men
}

\author{
Nur Allan Lasido \\ Prodi Ilmu Komunikasi Universitas Paramadina, Jakarta
}

\begin{abstract}
Abstrak
Kecenderungan perawatan tubuh telah bergeser menjadi milik pria saat ini. Industri kosmetik berlabel khusus pria marak diiklankan di media massa. Semakin banyaknya pria tampil dengan tingkat mobilitas tinggi serta terlibat dalam berbagai kesibukan, mengharuskan pria tampil modis (dandy), sekaligus, pada saat bersamaan, telah mengukuhkan dirinya menjadi bagian dari kebudayaan populer, dalam cirinya sebagai pria metroseksual. Dengan mengunakan analisis semiotika Roland Barthes, penelitian ini membedah dua citra visual (foto) iklan 'Veseline Men'. Dengan demikian, penelitian ini diharapkan mampu menelaah penciptaan citra, pada tataran denotatif (pesan harfiah) dan pada tataran konotatif (pesan simbolik), pada satu sisi; dan membongkar tataran konotasi di mana mitos 'bersemayam' sebagai strategi menanamkan keyakinan pada rancangan produk iklan untuk segmentasi pria. Hasil penelitian menemukan bahwa metroseksualitas dan maskulinitas sebagai mitos dalam rancangan produk iklan tersebut, yaitu sebuah naluri laki-laki sebagai petualang, penuh percaya diri dan sebagai simbol 'kepahlawaan'. Sementara pada tataran konotatif, iklan 'Vaseline Men' menunjukkan konstruksi ciri-ciri ideal bagi trend identitas kehidupan kelas menengah, yang meliputi sportivitas,, menjunjung tinggi panampilan fisik, konsumen aktif citra simbolik, termasuk kebiasaan memperhatikan kebersihan tubuh.
\end{abstract}

Kata Kunci: Metroseksualitas, Maskulinitas, Semiotika

\begin{abstract}
The current trend of body treatments has been shifted. It does not only belong to the woman but also belong to man. The advertisement of cosmetics industry for men is now growing up in the mass media. Using semiotic analysis developed by Roland Barthes, this study analyzed two visual images (photos) in 'Vaseline Men' advertisement, one of men body treatment product. This study aims to: 1) examining the creation of the image, from the denotative level (literally) to the connotative level (symbolic message). 2) investigating the myth that using as a rethorical strategy of advertising products that subjected to the men. The results found: 1) metrosexual and masculinity emerge as myths in this ads. The image represents a male instinct as adventurous, confident and man as a 'hero' that exactly related to the myth of metrosexual and masculinity 2) 'Vaseline Men' ads signification shows the imagination of 'ideal'man for the middle class, such as sportsmanship, good looking, active consumer of symbolic image, and have much attention to cleanliness of the body.
\end{abstract}

Keywords: Metrosexuality, Masculinity, Semiotics 


\section{Pendahuluan}

Etos pascafordisme dapat diamati pada menguatnya sektor konsumsi dari sebelumnya yang lebih menitikberatkan pada sektor produksi. Ciri pascafordisme ini dapat ditelusuri melalui dukungan teknologi informasi dan hasil produksi yang lebih menekankan pada tipe konsumen serta segmentasi pasar pada kelas sosial terentu (Hall 1988: 24). Ini bisa dilihat, misalnya, pada kemunculan beragam produk-produk tertentu, seperti fashion, jasa kecantikan dan kosmetik. Meskipun konsumen industri kosmetik masih didominasi perempuan, tapi pola merawat dan memperhatikan diri/tubuh tampaknya bukan lagi hanya urusan perempuan semata. Kecenderungan perawatan tubuh kini telah mulai bergeser kepada pria.

Selama ini, pasar kosmetik pria lebih kompetitif. Senior Brand Manager PT Beiersdorf Indonesia (produsen Nivea For men), Pratitis Adi Nugraha, misalnya, mengatakan bahwa kaum pria di Indonesia sudah mulai peduli dengan penampilan, mau merawat tubuh mereka demi meningkatkan kepercayaan diri (swa.co.id: 2012). Oleh karena itu, pasar pria seperti menemukan lahan garapan baru, khususnya industri kosmetik. Ini karena semakin banyak pria tampil dengan tingkat mobilitas tinggi serta terlibat dalam berbagai kesibukan. Selain itu, interaksi publik mengharuskan pria tampil modis (dandy), sekaligus pada saat bersamaan telah mengukuhkan dirinya menjadi bagian dari kebudayaan populer.

Penelitian yang dilakukan oleh Tri Handoko (2005) menyebutkan bahwa fenomena metroseksual muncul serta menjadi peluang bagi para produsen dalam menjaring eksekutif muda untuk memanfaatkan waktu luang (leisure time) di luar rumah, seperti ke mall, music lounge, club, salon, dan Spa. Dahulu, bagi para pria, urusan fashion dan perawatan tubuh bukanlah yang utama. Bahkan, para pria yang peduli pada perawatan tubuh dan fashion sering diberi label bergaya perempuan. Namun sekarang, terdapat kecenderungan baru dimana aktivitas konsumsi atau belanja kebutuhan tidak lagi didominasi oleh kaum perempuan, tapi juga kaum pria. Para pria ini tidak hanya gemar belanja aksesoris fashion, tetapi juga merambat pada perawatan tubuh, wajah dan kulit (swa.co.id:2012). Merek fashion yang dahulu didesain khusus kaum perempuan, seperti 'Esprit', kini mulai menjual produknya untuk pria (www.esprit.co.uk:2015). Demikian juga dengan 'Veseline', salah satu produk pembersih. Awalnya, produk ini khusus perempuan, tapi sekarang para pria pun menggunakannya.

Saat ini, di pusat perbelanjaan, jenis pakaian pria beserta aksesorisnya semakin beragam dengan warna-warna yang semakin variatif. Kemunculan produk tersebut bukanlah tanpa sengaja. Hal ini bisa ditelusuri pada aktivitas periklanan dan pemasaran. Produsen melalui proses kreatif merancang iklannya melalui pengunaan ikon-ikon ternama yang ber-style modis. Khusus target pasar di Indonesia sekitar awal tahun200o-an memanfaatkan talent seperti Ferry Salim, Ari Wibowo, dan model-model lainnya berhasil membuat sebuah terobosan baru dalam peta pemasaran produk dengan menciptakan kebutuhan baru bagi kaum pria. Produk tersebutn membentang mulai dari pembersih wajah, pelembab muka, wangi-wangian, pewarna rambut, sabun mandi, shampo, bedak tubuh, dan sebagainya (Tri Handoko: 2005).

Penggarapan pasar pria ini sebenarnya dimulai sejak lama oleh Biore melalui produk sabun mandi cair dan sabun pembersih wajah dengan merek 'Men's Biore'. Rasanya, cukup lama brand ini melenggang sendirian. Tepat pada 1994, produk sabun cuci muka khusus pria ini sudah beredar luas di pasaran seiring menguatnya aktivitas promosi di media massa saat itu. Beberapa tahun kemudian, sekitar 20052015, hadir produk lainnya seperti Men's Expert dari L'OREAL, produk perawatan kulit khusus pria. Selain itu, Nivea for Men dari Beiersdorf juga memasuki persaingan. Persaingan produk perawatan kulit khusus pria ini semakin sengit sejak Unilever Indonesia meluncurkan merek Vaseline MEN sejak 2010 lalu (Sulamali: 2011)

Kehadiran produk-produk pembersih wajah yang diformulasikan khusus pria seperti ‘Vaseline Men', seolah 
menjawab kebutuhan pria masa kini. Perawatan pria pada segmen pembersih dan perawatan kulit di Indonesia berdasarkan survei yang diliris Vaseline (2009) mengalami pertumbuhan signifikan. Penjualan produk perawatan pria tumbuh sekira 46,5 persen, sedangkan pembersih tumbuh sekira 32,9 persen di tahun 2009. Hal ini menunjukkan adanya pergeseran pandangan mengenai perawatan kulit pria. Hasil surveiVaseline inilah yang kemudian mendorong Vaseline meluncurkan rangkaian produk perawatan kulit pria, yang meliputi facial wash, body lotion dan body wash (Lihat: produk life sytle, 'Veseline' jawab kebutuhan pria masa kini'. Padawww.okezone.com :2010)

\section{Kuasa Iklan Sebagai Objek}

\section{Seksualitas}

Iklan sebagai sebuah teks adalah sistem tanda yang diorganisasikan menurut kode-kode yang merefleksikan nilai-nilai tertentu, sikap, dan keyakinan tertentu. Setiap pesan dalam iklan memiliki dua tingkatan makna, yaitu makna yang dikemukakan secara eksplisit di permukaan dan makna yang dikemukakan secara implisit di balik permukaan (Noviani, 2002: 79)

Jika sebelumnya iklan di media massa dalam segala bentuk media: cetak, elektronik dan digital kerap kali memposisikan perempuan sebagai objek kepentingan seksualitas laki-laki yang berakhir pada komodifikasi seksualitas perempuan, maka tidak demikian yang terjadi saat ini. Laki-laki juga ikut terjebak dalam komodifikasi seksualitasnya. Asumsi ini yang ingin penulis dalami terkait penggunaan produk kosmetik khusus pria.

Iklan tidak hanya berperan sebagai strategi promosi pada perebutan konsumen pria untuk sebuah produk perawatan tubuh. Namun, bertindak mengarahkan dan memposisikan laki-laki sebagai objek seksual. Iklan menciptakan standar baru masyarakat untuk laki-laki, yakni sebagai sosok yang agresif sekaligus sensitif, memadukan antara unsur kekuatan dan kepekaan sekaligus. Jika dulu konsep maskulinitas lama dicirikan pada Laki-laki macho (berotot kekar), maka saat ini telah digantikan oleh sosok laki-laki yang modis (dandy), nampak kuat dan tegar di dalam, tetapi lembut di permukaan. Ungkapan untuk karakter laki-laki metrosekual (maskulinitas baru). Berdasarkan pokok persoalan di atas, pertanyaan penelitian yang diajukan dalam penelitian ini adalah bagaimana Penciptaan citra, pada tataran denotatif (pesan harfiah) dan pada tataran konotatif (pesan simbolik), dalam membangun identitas tertentu untuk produk Vaseline men, termasuk di dalamnya suatu "kepribadian" bagi produk itu sebagai ekspresi kultural sehingga memperkuat posisinya pada target pasar yang dituju. Terlebih pada tataran konotasi, sebuah mitos 'bersemayam' sebagai strategi menanamkan keyakinan pada rancangan produk iklan.

\section{Landasan Teori dan Metodologi}

\section{Relasi Tanda dalam Semiotika Roland Barthes}

Roland Barthes adalah nama besar ahli semiotika yang menelaah selubung makna denotasi dan mitos. Melalui teori semiotikanya, Barthes menyatakan bahwa ada dua sistem pemaknaan tanda, yakni denotasi dan konotasi. Sistem denotasi adalah sistem pertandaan tingkat pertama, yang terdiri dari rantai penanda dan petanda, yakni hubungan materialitas penanda atau konsep abstrak di baliknya. Pada sistem konotasi-atau sistem penandaan tingkat kedua-rantai penanda/petanda pada sistem denotasi menjadi penanda, dan seterusnya berkaitan dengan petanda yang lain pada rantai pertandaan lebih tinggi (Barthes dalam Berger, 67: 2010).

Dalam peta semiotika Barthes, terlihat bahwa tanda denotatif terdiri atas penanda dan petanda. Namun, pada saat bersamaan, tanda denotatif adalah juga penanda konotatif. Jadi, dalam konsep Barthes, tanda konotatif tidak sekadar memiliki makna tambahan, tapi juga 
mengandung kedua bagian tanda denotatif yang melandasi keberadaannya. Pada dasarnya, ada perbedaan antara denotasi dan konotasi dalam pengertian secara umum serta denotasi dan konotasi yang dipahami oleh Barthes. Dalam semiologi Barthes dan para pengikutnya, denotasi merupakan sistem signifikasi tingkat pertama, sementara konotasi merupakan tingkat kedua. Dalam hal ini, denotasi justru lebih diasosiasikan dengan ketertutupan makna. Sebagai reaksi untuk melawan keharfiahan denotasi yang bersifat opresif ini, Barthes mencoba menyingkirkan dan menolaknya. Baginya, yang ada hanyalah konotasi. Ia lebih lanjut mengatakan bahwa makna "harfiah" merupakan sesuatu yang bersifat alamiah (Budiman, 1999:22). Dalam kerangka Barthes, konotasi identik dengan operasi ideologi, yang disebutnya sebagai 'mitos'. $\begin{array}{cccc}\text { Bagi } & \text { Barthes } & (1983: 109 & \text { dalam } \\ \text { Budiman, } & \text { 2011: } & 38), & \text { bahasa }\end{array}$ membutuhkan kondisi tertentu untuk dapat menjadi mitos, yaitu yang secara semiotik dicirikan oleh hadirnya sebuah tataran signifikasi yang disebut sebagai system semiologis tingkat kedua (the second order semiological system) penanda-penanda berhubungan dengan petanda-petanda sedemikian sehingga menghasilkan tanda. Selanjutnya, tandatanda pada tataran pertama pada gilirannya hanya akan menjadi penandapenanda yang berhubungan pula dengan petanda-petanda pada tataran kedua. Pada tataran signifikasi lapis kedua inilah, mitos bercokol (Barthes , 1983: 114-115 dalam Budiman, 2011:38). Berikut skema model semiotika dari Roland Barthes.

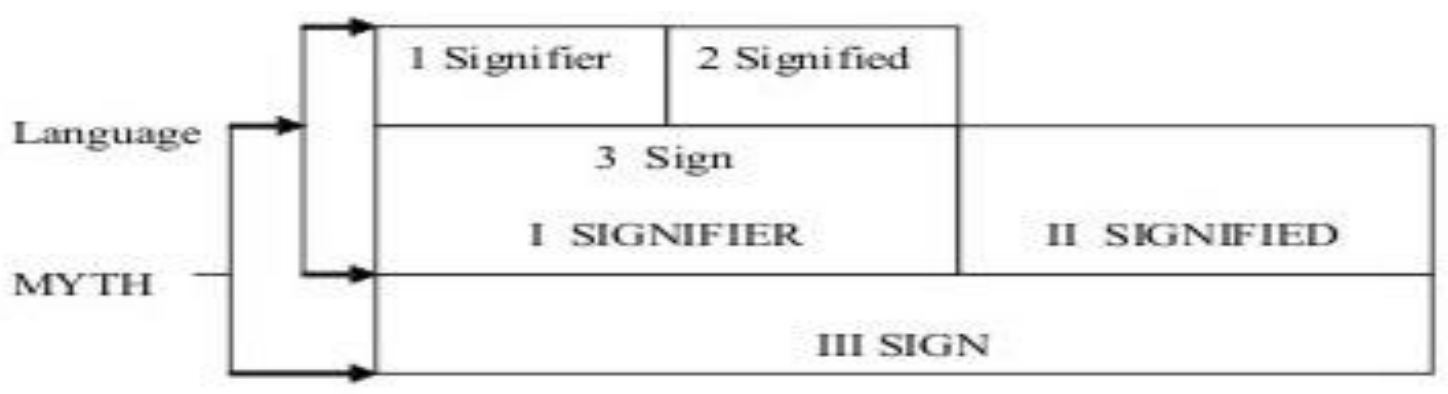

Berpijak dari paparan di atas, penulis mengunakan pendekatan kualitatif-eksplanatif. Pemaparan terfokus pada dua teks (foto). Namun, dimungkinkan merujuk pada citra visual lainnya sepanjang masih sesuai konteks penelitian. Selanjutnya, penulis merumuskan pertanyaan penelitian semiotika terkait dengan iklan produk kosmetik (pembersih wajah) khusus lakilaki, yaitu Vaseline Men yang terdapat pada harian Kompas cetak edisi 20 April 2010.

\section{Pembahasan}

\section{Proses Semiosis Iklan 'Veseline Men'}

Pada tahap anlisis ini, penulis mencantumkan dua citra (foto) iklan Vaseline Men dengan mengunakan pendekatan analisis semiotika Roland Barthes untuk menjawab pertanyaan penelitian. Pada tataran bahasa(language) sebagai sistem semiologis tahap pertama dalam citra ikonik (fotografi) atas dua iklan Vaseline Men, penulis menemukan penanda (signifier) yang terdiri dari elemen-elemen berikut (lihat tabel 1) 

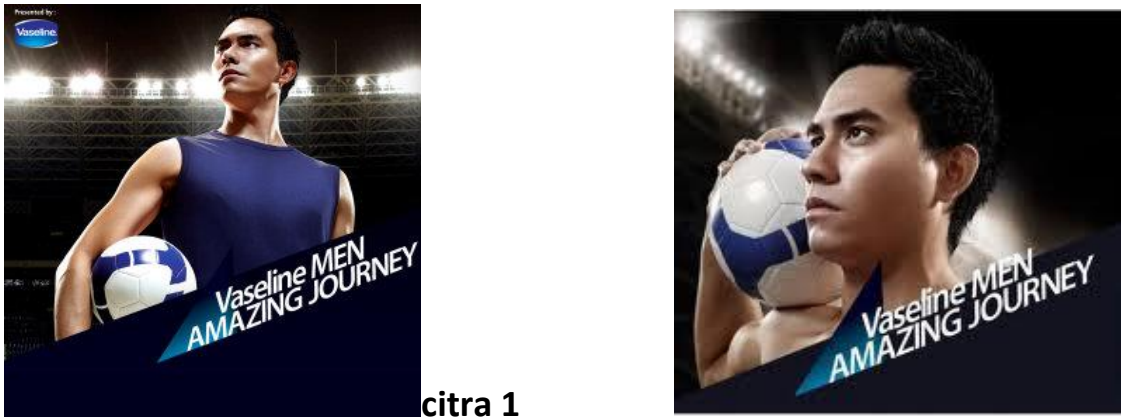

citra 2

Tabel 1

Elemen Penanda Iklan Vaseline Men

\begin{tabular}{|ll|}
\hline \multicolumn{1}{|c|}{ Penanda/Signifier } \\
\hline 1. & \multicolumn{1}{|c|}{ Seorang atlit sepak bola } \\
2. & Lengan yang mengapit sebuah bola \\
3. Posisi badan menghadap menyamping memperlihatkan postur \\
dada, otot lengan. tulang rahang yang persegi \\
4. Raut kulit dan wajah bersih dan bersinar \\
5. Mengunakan kostum tanpa lengan bercorak biru \\
6. Latar cahaya lampu stadion \\
7. Ekpresi wajah dan mata yang menatap tegak kea rah penonton \\
8. Terdapat teks "Vaseline men Amazing journey" \\
9. Sebuah logo produk"vaseline men" \\
\hline
\end{tabular}

Dari penanda dalam citra (foto) iklan Veseline di atas, penulis menemukan ada sembilan ciri penanda sebagai aspek material yang melekat pada citra iklan 'Veseline Men'. Selanjutnya, sembilan penanda ini sedikitnya mengandung dua tema besar yang nantinya akan merujuk atau berhubungan dengan petanda sebagai berikut.

- Maskulinitas. Maskulinitas terwakili dalam kesan sportif penuh tantangan, sedangkan penampilan fisik tubuh berotot yang mencitrakan tubuh ideal lakilaki. Sebuah bentuk fisik yang hanya bisa didapatkan melalui latihan olah raga yang memadai. Imaji seperti itu banyak muncul di iklan parfum seperti Axe Perfect atau iklan susu $L$ Man yang mengumbar dada telanjang, kepadatan otot perut dalam bentuksix pack,menjadi imaji yang ideal bagi performativitas laki-laki. Disamping itu, media telah mengekspresikan dan

mengkonstruksi imaji laki-laki kerap kali digambarkan dengan sikap mandiri, bijak mengambil keputusan, agresif, dan mempunyai jiwa kompetisi.

Klimis. Klimis merujuk pada kesan teratur atau dengan kata lain selalu berkeinginan tampil rapi. Memperhatikan penampilan seperti perawatan tubuh dan pilihan fashion. Ini dilakukan salah satunya melalui praktik konsumsi, yaitu membeli produk demi menjaga penampilan diri dan citra diri. Kosumen pria seperti ini pada umumnya mempunyai ciri khas dalam berpakaian, 
berdandan, gaya rambut, dan sebagainya bertujuan agar selalu berpenampilan menarik.

Pada lapisan pertama (pesan denotatif) atau disebut juga pesan harfiah dalam citra iklan Veseline, yaitu "Seorang atlet sepak bola dengan raut wajah bersih bersinar menatap ke arah penonton." Pada tataran pertama ini, citra (foto) sebagaimana disebutkan oleh Barthes merupakan citra analogon (kopian) yang sempurna dari realitas secara langsung dan jelas. Kesempurnaan analogis inilah yang diterima oleh masyrakat sebagai ciri kekuatan foto meniru objek/realitas dimana fotomenjadi pesan tak berkode (Barthes :1977:18).

Pada citra ikonik petanda lapisan pertama, yaitu "seorang atlet sepak bola beraut muka bersih menatap ke penonton" adalah murni denotasi sebagai realitas literal yang mudah teramati sehingga objektivitas iklan foto tersebut memiliki kemungkinan menjadi mitos. Seperti pernyataan Barthes, "This purely 'denotative' status of the photograph, the perfection and plenitude of its analogy, in short its 'objectivity', has every chance of being mythical (these are the characteristics that common sense attributes to the photograph) (1977:19).”

Pada tataran mitos (konotasi), yakni sistem semiologis lapis kedua atau pesan simbolik, dimana tanda - tanda pada tataran pertama tadi telah menjadi penda-penada yang berelasi lagi dengan petanda-petanda (Budiman: 2011: 39), direpresentasikan ke dalam "Gaya hidup pria modern yang identik dengan perhatian pada penampilan diri, bersih, sportif dan berwibawa.”. Representasi itu melebur ke dalam sebuah proses tataran mekanisme semiotika lapis kedua, dimana tanda pada tahap pertama (denotatif), yaitu seorang atlet sepak bola dengan raut wajah bersih bersinar menatap ke arah penonton menjadi penanda bagi tahap kedua (konotatif). Untuk menemukan mitos yang bersemayam pada lapis kedua ini, penanda tadi telah merujuk (berelasi) pada petanda yang sudah terbentuk dalam struktur budaya atau ideologi tertentu,yakni mitos pria metroseksulitas dan maskulinitas.

\section{Prosedur Tahap Konotasi Citra}

Sebelum penulis mengurai lebih jauh mitos metroseksualitas dalam iklan Vaseline Men, terlebih dahulu penulis akan memeriksa bagaimana tahapantahapan konotasi ini tersusun dalam citra (foto) iklan Veseline. Sebagaimana dikemukan Barthes dalam karyanya Image, Music Teks, konotasi merupakan proses imposisi (pelapisan) makna kedua atas pesan fotografi yang terjadi dalam beberapa tahapan berbeda yang merupakan bagian dari proses panjang produksi foto (pemilahan teknis, framing dan tata letak) memperlihatkan suatu proses pengkodean analog fotografis (Barthes, 1977: 17). Dalam penjelasan Barthes, setidaknya, terdapat enam tahapan konotasi citra, yang meliputi efek tiruan, pose/sikap, objek, fotogenia, estetisisme, dan terakhir sintaksi. Berikut identifikasi ke-enam tahapan tersebut. 


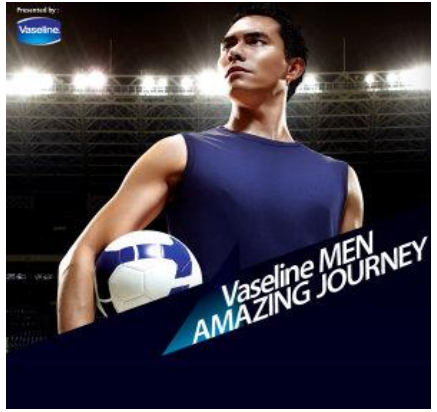

Foto 1

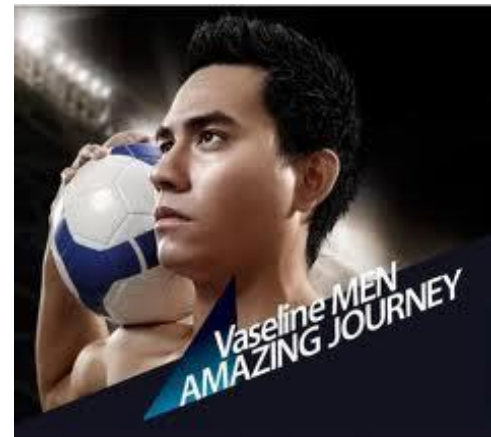

foto 2

\section{- Efek tiruan,}

Pada tahap ini, penulis tidak menemukan adanya perbaduan dua gambar dalam satu gambar

\section{- Pose}

Pada foto 1 dan foto 2, subjek adalah seorang atlet sepak bola yang diperankan oleh Darius Sinatra dengan posisi badan berdiri tegak menyamping, tatapan mata lurus, membusungkan dada, tulang rahang yang persegi, dada yang bidang, bahu yang lebar, tubuh yang berotot dan mengapit bola. Pose ini mencerminkan sikap atletis citra maskulinitas, suatu pengambaran imaji maskulinitas yang tangguh, mandiri, dan berani menerima tantangan karena dikaitkan dengan aktivitas fisik. Dengan demikian, imaji maskulin dalam iklan ini telah mengukuhkan laki-laki dinggap sebagai sang pahlawan pada segala medan. Sebagai sebuah produk, Vaseline Men telah dimaknai lebih dari sekadar pembersih wajah. Vaseline telah menggiring sensasi imaji maskulinitas dalam nalar masyarakat tontonan, citra maskulin telah terwakilkan pada label Vaseline Men.

\section{- Objek}

Terlihat pada penataan latar berupa stadion dan penggunaan atribut berupa kostum/seragam pemain sepak bola dan penambahan sebuah bola. Komposisi ini merujuk pada makna sportifitas (maskulinitas). Penataan dekoratif berupa latar sebuah stadion telah mengkostruksi olah raga (sepak bola) sebagai seolah standar nilai bagi rujukan makna maskulinitas. Sepak bola, bagaimanapun hampir selalu diidentifikasi dengan maskulinitas. Kelelakian, dan jarang ada yang mengelak, seperti identifikasi permukaan di atas, sepak bola adalah olah raga yang "nglanangi". Olah raga yang membuat seorang lelaki tampak lebih lelaki ataupun istilah yang dapat menggambarkan maskulinitas sepak bola, yang jelas ikut campurnya "yang bukan lelaki" dianggap sebagai sesuatu yang unik, aneh, disambut berlebihan, bahkan tak jarang dipandang sebelah mata.

- Fotogenia (pengaturan efek cahaya)

Pada dua foto tersebut, terlihat eksposur pencahayaan yang dominan mengarah pada wajah subjek, setting pencahyaaan latar sebuah stadion 
yang dibuat seolah tertuju pada subjek iklan sehingga menghasilkan modus terang dan bersinar. Disamping itu, adanya manipulasi make-up atau tatarias termasuk juga pilihan warna dominan dan kostum biru tua (indigo) semakin menguatkan citra sosok sportif (maskulin) penuh kepastian, petualang dan tenang

\section{- Estestisme}

Kedua foto ini telah menyerupai sebuah "poster" dimana kehadiran citra ikonik dibuat layaknya seperti lukisan yang memancarkan kesan natural sosok pria metroseksual.

\section{Narasi Citra Metrosekual Dalam Bingkai Gaya Hidup (Proses Pengabungan Teks Dan Citra)}

Menurut Barthes (dalam Budiman, 2011: 44), sebuah citra sebenarnya bukanlah suatu struktur yang tertutup karena setidak-tidaknya ia berkomunikasi dengan suatu struktur lain, yaitu teks. Dalam hal ini, apa yang dimaksud dengan teks adalah semata susunan kata, perkataan-perkataan atau kalimat-kalimat yang bersifa parasit dan sengaja dirancang untuk mengkonotasikan citra. Oleh karena itu, pesan tipe kedua ini dapat juga disebut pesan lingual yang hadir dalam nyaris setiap citra. Pesan kebahasaaan ini mungkin dapat berfungsi sebagai penambat atau pemancar. Dengan demikian, pada citra iklan Veseline Men di atas, pada tataran tahap pertama (denotatif), yakni seorang atlit sepak bola dengan raut wajah bersih bersinar menatap ke arah penonton berpotensi memiliki banyak makna. Oleh karenanya, salah satu teknik untuk mengunci atau mengikat rangkaian petanda-petanda yang mengapung diperlukan pembubuhan, yakni suatu cara yang berfungsi semacam penambat bagi segenap kemungkinan makna objek, mengarahkan pembaca kepada petandapetanda tertentu kepada makna-makna tertentu (Budiman, 2011: 44-45)

Salah satu teks berfungsi sebagai penambat pada citra ikan Vaseline Men versi Darius Sinatra terlihat jelas pembubuhan teks, yakni Vaseline man Amazing Journey. Pada foto iklan tersebut, kalimat ini turut menegaskan dan juga mengarahkan penafsiran pembaca kepada sebuah petanda atas kemungkinan makna tentang maskulinitas dan metroseksualitas. Sebuah pernyataan terkait dengan naluri laki-laki sebagai petualang, penuh percaya diri, dan sebagai simbol 'kepahlawaan'.

Berdasarkan uraian pada tahapan konotasi ini, penulis menemukan bahwa iklan Vaseline Men menunjukkan betapa pesan konotasi telah mengidentifikasi ciriciri ideal bagi kecenderungan identitas kehidupan kelas menengah ke atas, yang meliputi sportifitas (maskulinitas), menjunjung tinggi panampilan fisik, sebagai konsumen aktif citra simbolik, termasuk kebiasaan memperhatikan kebersihan tubuh dan bentuk-bentuk praktik fetisisme dalam suatu lakon tentang mitos pria metroseksultas sesuai yang dicitrakan subjek (bintang iklan). Dalam kaitan ini, kehadiran subjek (selebriti) sebagai bintang iklan atau disebut sebagai product endorser disebabkan selebritas lebih terkait dengan representasi individual dalam segala bentuknya ketimbang dengan orang yang terkait dengan institusi tertentu (Hartley, 2010: 271). 
Dipilihnya Darius sebagai product endorser Veseline Men telah bertindak dan bertingkah laku sebagai tanda sekaligus sebagai teks iklan yang di dalamnya menyediakan makna agar dengan konsep itu para konsumen media dapat menegosiasikan dan mencerna subjektivitas personalnya. Hal ini diharapkan bahwa cerita yang memiliki keterkaitan degannya akan selalu memuat orang-orang di luar dirinya dalam mencerna pesonanya hingga seolah-olah setara dengan subjek iklan (bintang iklan). Nilai keseharian yang ada dalam diri selebritas (Darius) telah menyebabkan dia sebagai 'representasi' ideal bagi sasaran pasar untuk memberikan dorongan, termasuk juga memberikan kesaksian atas keungulan produk pembersih wajah khusus pria, dalam hal ini Veseline Men.
Sebagai berbandingan, penulis mencantumkan iklan Vaseline Men versi Kane Theeradeth, selebritas Thailand. Dalam figure iklan Vaseline Men tersebut, penulis mengamati wajah Kane Theeradeth dan kemasan produk Vaseline ditempatkan sejajar secara bersamaan. Artinya seolah-olah iklan tersebut benarbenar merepresntasikan dua objek yang dimaknai sama, tetapi pada kenyataannya transfer makna ini hanya terjadi di dalam iklan 'Vaseline Men' hanya memilki citraan yang digunakan oleh selebriti Kane Theeradeth melalui pengasosiasianya kepada citra wajah Kane Theeradeth terhadap iklan itu sendiri. Jadi apa yang dimaksudkan wajah Kane theeradeth kepada khalayak melaui iklan Veselin Men adalah apa yang diupayakan oleh produk tersebut untuk disampaikan kepada kita dalam bentuk yang paling primodial melalui konsumsi produk.

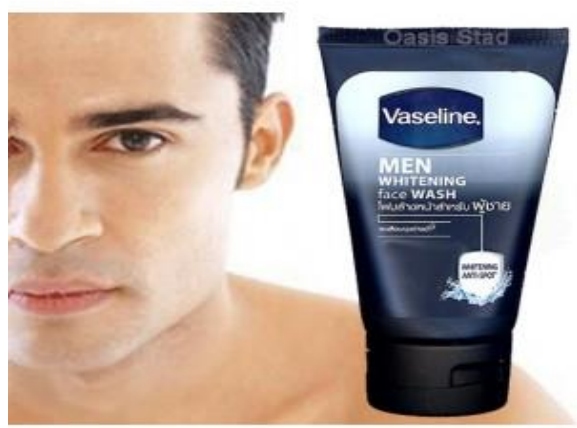

Fugur Kane Theeradeth dalam iklan Vaseline men 
Sebagai produk, iklan Vaseline Men mengunakan bahasa mitos yang saling berelasi dalam penanda (Kane Theeradeth) dan petanda (daya tarik/ketampanan) untuk membentuk produknya dari sudut pandang relasi yang sama. Oleh karenanya, produk Vaseline Men tersebut jadi rujukan bagi wajah Kane Theeradeth, serta bisa juga dibuat untuk menandakan ketampanan dan relasi kultural sebagai tanda dari keThailand-nya.

Dari sini, dapat diamati bahwa Darius Sinatra dan Kane Theeradeth memiliki suatu citra, yaitu signifikasi dalam satu sistem tanda. Mereka dapat digunakan untuk menciptakan signifikasi baru yang berhubungan dengan Vaseline Men, yaitu identitas pria metroseksual. Seandainya mereka bukan selebritas (aktor) dan tidak dikenali ciri popularitasnya, ketampanan, sportifitas, ke-Indonesiaa-nya dan ke-Thailand-nya, maka hubungan yang terbentuk antara wajahnya dan produk Vaseline Men tentu akan menjadi tidak bermakna. Jadi, bukanlah wajahnya saja, melainkan posisi wajah itu hadir dalam sistem tanda, terutama pada tataran kedua (konotasi) ketika bintang iklan tersebut bergerak dalam referen (rujukan) pada aspek streotipe kultural yang membuat Veseline Men bernilai jual. Ini berarti bahwa relasi antara citra dan realitas dipahami membingkai dunia yaitu, merujuk pada konteks sosial dan budaya setempat. Sebuah foto adalah bingkai dunia (diri seseorang) dalam pengertian foto tersebut mengambil sebagian atau seluruh diri sesorang dan lingkunganya. Dalam pengertian yang sama, citra itu membingkai konteks sosial yang dilukiskannya, termasuk dunia gaya hidup. Citra, dengan demikian, adalah cara pembingkaian gaya hidup melalui mekanismenya sendiri sehingga pandangan seseorang tentang sebuah kelompok sangat dipengaruhi oleh bagaimana kelompok itu ditampilkan atau menampilkan dirinya (Piliang, 2011: 321). Untuk koteks ini, bisa diamati bagaimana penampilan atau performativitas laki-laki dicitrakan dalam iklan Vaseline Men melekat dengan nilai-nilai maskulinitas yang membentuk konsep-konsep gaya hidup yang dicitrakan dan penuh akan muatan artificial, reduksionis, palsu, imanen, dan simulatif. Pada tataran ini, dapat dipahami ada semacam proses reduksi subjek ke dalam bingkai alienasi, yaitu terperangkapnya manusia di dalam subjektivitas palsu melalui dunia citra yakni citra gaya hidup urban dan manusia diredusir ke dalam ontologi citra, sambil mengasingkan diri dari diri yang sesungguhnya (Toril Moi 1985: 164 dalam Piliang.2011: 321)

Citra hanya bisa berfungsi bila ia digunakan dalam praktik sosial yang di dalamnya diperlukan sebagai cara atau mekanisme dalam penciptaan perbedaan sosial berdasarkan umur, gender, suku, ras, bangsa, profesi maupun kelas sosial, yang setiap bentuk tersebut memerlukan citra untuk mengaktualisasikan atau mengkongkretkan perbedaan tersebut. Dalam Masyarakat dibedakan atas kelompok-kelompok gaya hidup yang masing-masing mengandalkan identitas pada kelompoknya pada sebuah sistem citra.

Sebagai satu bentuk pembedaan sosial gaya hidup itu sendiri juga dimaknai dengan cara yang berbeda. 
David Chaney dalam lifestyle (2002) menjelaskan gaya hidup sebagai gaya, tata cara, atau cara mengunakan barang, tempat dan waktu, khas suatu masyarakat ternetu, yang sangat bergantung pada bentuk-bentuk kebudayaan. Dengan demikian, maskulinitas tidak lain adalah komoditas itu sendiri. Ia digunakan produsen dalam indusrti periklanan, dan turut memberikan janji-janji sebuah pemecahan masalah bahwa maskulinitas bagi laki-laki bisa didapatkan dari produk yang mereka tawarkan atau produk yang dihadirkan produsen. Tujuan akhirnya adalah keuntungan ekonomi bagi produsen atas produk tersebut seperti berolahraga, bermain musik, ataupun yang bersifat gaya hidup kosmopolit 'dugem' di pub atau diskotik. Di luar itu, bisa juga semangat solidaritas pada kelompok/pertemanan yang berafiliasi dengan kalangan muda. Citra berselera elit dan berkelas adalah representasi hasil konstruksi pesan-pesan simbolik dalam produk iklan berciri maskulin. Keduanya menjalin makna sesuai dengan ideologiyang diusung oleh iklan, sekaligus tak lebih sebagai tubuh-tubuh yang 'dipamerkan' dalam label sebuah nilai jual.

\begin{abstract}
Sebagai sebuah mitos, metroseksual menjadi tanda yang memiliki relasi dengan karakter konsumennya yang khas seperti terkait tingkat pendidikan, kelas sosial, sikap sosial dan gaya hidup yang menciptakan identitas yang dapat dikenali dari suatu produk dengan tujuan untuk menarik minat konsumen pria. Mitos itu dimunculkan dalam teks iklan, secara harfiah dapat dilihat pada orang-orang yang tampil di iklan itu, yakni orangorang yang tampil 'keren'dengan ciri penampilan tertentu. Akhirnya, pengiklan (kreator) seperti itu menampilkan bukan produk semata, tetapi makna sosial berupa maskulinisme, sportivitas dan metroseksulitas dan higenitas (menjujung kebersihan tubuh) yang diharapkan terwujud jika konsumen pria membeli produk Vaseline Men
\end{abstract}

\section{Mitos Metroseksualitas dalam Narasi “Aku Ideal”}

Tentunya, tidak hanya di Indonesia, ekspansi pasar produk Vaselin Men juga mewarnai beberapa Negara. Salah satunya di India. Iklan Vaselin Men versi bintang iklan Shakh Rukh Khan cukup mendapat perhatian publik di Negara itu (www.cnn.com, 2010). Berikut figure iklan yang dimaksud.

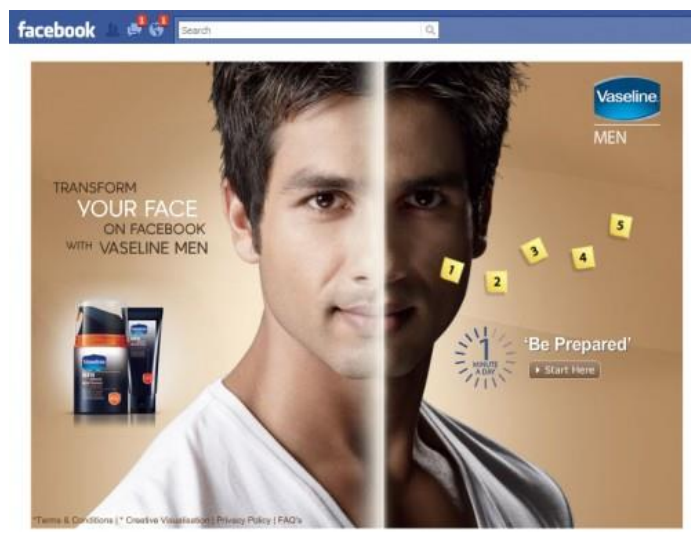


Satu hal menarik yang ingin penulis tekankan adalah bagaimana identitas pria teralienasi melalui citracitra ideal yang membentuk diri mereka sebagai salah satu objek dalam pertukaran citra-citra dalam iklan. Ini karena iklan sebagai suatu aparatus ideologis, sebagai sistem pertandaan dalam wilayah simbolik, mampu merepresentasikan kembali subjek pada kedudukanya di wilayah imajiner. Oleh karena itu, iklaniklan turut merancang relasi aktif subjek (masyarakat) terhadap citra dalam iklan melalui penciptaan fiktif suatu diri terpadu dalam sebuah 'ideal ego' (Williamson, 2007: 93)

Dalam gambar di atas, citra bintang iklan Vaselin Men untuk pasar di India, Shakh Rukh Khan yang penandanya teramati berupa separuh wajah terlihat kontras (membelah) di satu sisi nampak putih bersih, di sisi lain tidak begitu putih tapi gelap. Dengan sederhana, penulis mengatakan bahwa tampilan kreatif citra iklan tersebut menunjukkan kepada Shakh Rukh Khan suatu simbol tentang 'diri Khan' dengan maksud untuk memikat hasrat subjek. Iklan tersebut ingin mengesankan bahwa Khan dapat menjadi person/sosok dalam gambar yang ada di hadapannya (gambar sosok/diri Khan di depan tampilan facebook). Namun, nampaknya, hubungan dengan citra diri Khan yang sudah terobjektifikasi menjadi'kemustahilan imajiner' berupa sesuatu yang hanya ada dalam citra visual produk iklan tersebut, bukan sebagai fakta yang sesugguhnya melekat pada diri objek yaitu diri Khan.

Kiranya, tepat jika penulis merujuk menggunakan konsep fase cermin menurut Jaques Lacan (dalam Evans, 1996: 142) bahwa hasrat akan tatapan diri kita tidak lain adalah ekspresi dari ego ideal. Tahap cermin menjelaskan pembentukan ego melalui proses identifikasi diri. Ego terbentuk ketika subjek mengikatkan dirinya pada imaji yang mengalineasikanya dari dirinya sendiri sehingga ego selamanya tidak dapat direduksi pada identitasnya yang hidup (Evans 1996, Williamson, 2007: 91) Pada tataran denotatif, iklan Vaselin Men versi Khan tersebut menampilkan Facebook sebagai medium yang mampu menjadi penentu kualitas kebersihan paras Khan. Tak ubahnya seperti cermin yang melibatkan antara Shakh Rukh khan, pada satu sisi, nampak cerah, tetapi, sisi lain, kulit Khan nampak tidak cerah (gelap). Facebook sebagai 'cermin' merefleksikan wajah ambigu Khan mengilustrasikan status sebuah objek yang terefleksi melalui citra cermin sebagai sosok ideal Shakh Rukh Khan telah diganti oleh yang 'bukan Shakh Rukh Khan'. Pada kenyataanya, Shakh Rukh Khan tetap sebagai objek iklan. Namun, karena dirinya telah dikuasai oleh citra tiruan dalam iklan sebagai objek yang terpisah antara yang dipandang ideal dan tidak ideal. Maka, untuk mendapatkan kembali obejek-objek yang hilang, Khan atau dalam konteks ini adalah konsumen produk pria yang menyadari memiliki masalah dengan wajah kusam, terbujuk membelinya, mengkonsumsinya dan menciptakan kembali diri mereka untuk mengidentifikasi diri yang ideal mengikuti standar ideal citra iklan tersebut.

Tidak berhenti pada aspek ini, bahkan menurut penulis, jika diperhatikan pada tataran konotatif gambar iklan tersebut menciptakan sebuah mitos tentang rasisme warna kulit 
yang dimiliki oleh beberapa warga di India. Mereka yang cenderung tidak putih, tapi seolah 'diputihkan' melalui aplikasi yang diluncurkan Vaseline ini. Mengajak pria di India untuk mengunduh foto profil mereka di Facebook dan memasukkan ke layar digital," Lighten my Skin". Ini adalah salah satu cara dari pihak Vaseline untuk mempromosikan produk Vaseline untuk pria di negara itu.

\section{Mitos Metroseksulitas:}

\section{Pendisiplinan Tubuh-Tubuh yang Patuh}

Barthes dalam Mitologi (2011) menyatakan bahwa mitos merupakan system komunikasi. Ia adalah sebuah pesan dalam sistem semiologi tingkat dua, yakni gabungan total antara konsep dan citra pada system pertama menjadi penanda pada system kedua (Barthes, 2011: 161).

Satu hal kiranya juga penting untuk dijadikan barometer 'ideal' atau 'tidak ideal' pria adalah bentuk tubuh. Billman (2004) menyebutkan bahwa "the masculine body conjures images of muscles, toughness and power."Hal ini menjelaskan bahwa pria yang "ideal" adalah mereka yang memilki otot, ketangguhan dan kekuatan. Dalam artikel yang sama, ia menyebutkan bahwa tubuh dijadikan sebagai salah satu barometer untuk mengukur maskulinitas seorang pria karena tubuh adalah hal yang paling mudah dilihat oleh publik.

Menurut penulis, penelitian ini turut membantah pandangan Laura Mulvey (1975) dalam artikel "Visual Pleasure and Narrative Cinema” (1975) terkait kuatnya tatapan mata laki laki (male gaze) atas perempuan. Namun, kehadiran produk maskulinitas seperti ini tidak saja "male gaze" yang berlaku, tetapi juga "female gaze" di mana pria dicitrakan sebagai "passive sex object". Sebagaimana pandangan Stuart Hall (1997), pria juga sama posisinya dituntut untuk mencapai 'standar' yang sudah dikonstruksi agar bisa disebut sebagai pria maskulin untuk kemudian masuk dalam kategori pria "ideal" dan tentunya diminati baik oleh lawan jenis maupun sesama jenis. Namun, patut ditekankan bahwa mengugatnya posisi tubuh tidak semata-mata sebagai eksponen biologis, tapi bagian dari ekpresi kultural. Tubuh telah menjadi semacam kontestasi dalam kebudayaan visual publik, mampu menembus batas-batas privat. Hampir setiap saat kita menyaksikan di televisi, billboard iklan, di majalah, koran, ataupun tabloid, di segala tempat, kerap kali bersentuan dengan citraan tubuh. Publik merasa dikepung oleh tubuhyang dikontrol itu hingga persoalan tubuh ikut pula mendefiniskan relasi kelas, ras, dan identitas termasuk juga tubuh harus patuh pada pelukan nilai dalam jebakan kapitalisme lanjut sebagai tubuh-tubuh yang terpamer dalam label sebuah nilai jual.

Berdasarkan penjelasan di atas, maka persoalan gender tidak semata-mata menjadi arena bagi perempuan saja. Pergulatanya bukan terfokus pada pelaku (perempuan dan laki-laki), tetapi lebih kepada sistem dan struktur budaya dominan yang hegemonik. Bagi penulis, budaya dominan adalah kuasa kapitalisme dalam beragam bentuk. Luruhnya batasan-batasan ini juga berimbas secara signifikan pula pada pola berpikir dan stereotip yang dibentuk oleh pola pemikiran modern tentang maskulinitas. Pria bagaimanapun telah melampaui batas-batas gender dengan melakukan 
suatu ritual, dalam hal ini perawatan tubuh, yang selama ini menjadi stereotip kaum hawa dalamkonstruksi sosial pada umumnya.

Pria menurut pandangan umum yang berlaku adalah sosok jantan, kekar, untuk menggambarkan dominasinya akan kekuasaan dan kelebihannya dibandingkan perempuan. Sosok yang semula dipandang kuat untuk melindungi 'perempuan' telah bergeser menjadi lebih sensitif akan penampilan. Kertajaya (2003: 21 ) menyebut ini sebagai Women revolution, dimana urusan pria sekarang ini tidak hanya bekerja dan mencari uang, tetapi juga memperhatikan penampilannya dan bersikap emosional. Salah satu contohnya adalah Darius Sinatra atau yang lebih tersohor seperti David Becham tidak hanya dikenal sebagai bintang lapangan. Ia kerap kali membintangi sejumlah produk khas pria. Inilah sederat gambaran atau ilustrasi bahwa imaji maskulinitas bukan lagi hanya perkara kejantanan semata, tapi bergerak menembus batasan dikotomis atas maskulin dan feminin.

Kalau melihat perkembangan metroseksual saat ini, bisa jadi bukanlah hanya kecenderungan sesaat saja. Media dan iklan yang terus menampilkan gaya dan kehidupan selebritas seperti Beckham atau Lionel Messi kerap tampil sebagai bintang iklan produk-produk berciri metroseksual menjadi gaya hidup dalam label 'kontemporer' semakin menunjang kearah itu. Terlebih, dukungan masyarakat yang semakin melek informasi dan tingginya gaya hidup konsumtif. Seperti diungkapkan oleh Harvey (dalam Strinati, 1995: 257), "citraan mendominasi narasi" dimana masyarakat sering mengkonsumsi citra maupun tanda itu sendiri, dan bukannya substansi, isi, dan maknanya/ kegunaannya. Tepatnya, metroseksual adalah sosok narcistic dengan penampilan dandy (pesolek), yang tidak jauh dari penampilan gaya dandan pria di media massa yang jatuh cinta tidak hanya terhadap diri sendiri, jatuh cinta terhadap tubuh hingga tanpa disadari telah melakukan pengaturan (regulasi) atas tubuh melalui beragam bentuk. Salah satunya difasilitasi oleh media mengkonstruksi gaya hidup metropolis (Santoso, 2004: 26)

\section{Simpulan}

Hasil analisis semiotika dengan mengunakan pendekatan Roland Barthes untuk mengkaji aspek pesan denotatif dan konotatif, menemukan aspek mitologis bahwa iklan Vaseline Men menyimpanan selubung gaya hidup metroseksual. Penyajian ilustrasi baik pada tahap linguistic dan tahap pesan simbolik menegaskan bahwa metroseksual menjadi rujukan cultural dalam konstruksi citra laki-laki. Akibatnya, kecenderungan gaya hidup metroseksual yang merambah kotakota besar semakin menunjukkan pengaruhnya. Awalnya sekadar wacana, kini telah merasuki dan menjadi kecenderungan kehidupan kelas menengah ke atas. Iklan dengan bentuk penawarannya yang glamour telah menawarkan nilainilai simbolik tertentu, didukung dengan globalisasi informasi dalam kehidupan manusia yang semakin konsumtif, menyebabkan gaya hidup metroseksual menjadi tidak sekedar fenomena lagi namun telah menjadi suatu identitas sosial yang membedakan si pemilik identitas tersebut dengan individu lainnya dalam kehidupan sosialnya. Dalam hal ini, gaya hidup konsumtif telah melahirkan lagi satu bentukannya melalui produk- 
produk gaya berpenampilan yang serba

glamour dan eksperimental pada pria.[]

\section{Daftar Pustaka}

Barthes, Roland. (1977).”Image, Music,Teks". Fontana Press

'Mitologi"'

(terj). (2011).Yogyakarta : Kreasi
Wacana.
Benny, Santoso. (2004) "Pria
Metroseksual," Get Life o6
Berger, Arthur. A. (2010) "Pengantar
semiotika: Tanda-tanda dalam,
kebudayaan
$\begin{aligned} & \text { Yogyakarta:Tiara Wacana. } \\ & \text { Kudiman, Kris. (2011) 'Semiotika Visual, }\end{aligned}$ konsep,isu dan proplem ikonitas". Yogyakarta: Jalasutra.

Evans, Dylan. (1996) 'An Introductory Dictionary of Lacanian Psychoanalysis 1st Edition' .London, Routledge

Hartley, Jhon. (2010)"communication, cultural and massa media (konsep kunci)’Yogyakarta: Jalasutra.

Hall, Stuart. (1997). 'Representation: Cultural and Signifying Practices'. London: Sage Publications

Hall, Stuart. (1988).'Brave new world. Marxism Today", October 1988, ebook www.unz.org
Noviani, Ratna. (2002)."Jalan Tengah Memahami Iklan” Pustaka Pelajar

Strinati, Dominic. (1995) 'Popular Culture: Pengantar Menuju teori Budaya Populer, terjemahan Yogyakarta, Bentang

Williamson, Judith. (2007) 'Decoding Advertisements" (terj). Yogyakarta: Jalasutra.

Piliang, Yasraf A,. (2011) "Dunia Yang Dilipat: Tamasya Melampaui Batas-Batas Kebudayaan”. Bandung: Matahari.

Website

Heri Sulamali (2011) 'Clash of The Titans - Men's Biore vs Vaseline MEN, battle of

metrosexualhttp://herisumali.wordpress.c om/

Handoko.Tri. (2005) 'Metroseksualitas Dalam Iklan Sebagai Wacana Gaya Hidup Posmodern"

www. Swa.co.id . (2012) 'Pasar Kosmetik Pria Naik 2 Kali

www.cnn.com. (2010)'Vaseline skinlightening app stirs debate" 